\title{
Effects of Size and Degree of Abdomen Inflation of the Mother Fish on Ovulation Induction of Red Spotted Grouper, Epinephelus akaara
}

\author{
Jong Youn Park ${ }^{1}$, Jae Kwon Cho', Young Jae Choi ${ }^{1}$, Kyeong Ho Han ${ }^{2}$, and ${ }^{\dagger}$ Chang Gi Hong ${ }^{1}$ \\ ${ }^{1}$ South Sea Fisheries Research Institute, National Institute of Fisheries Science, Yeosu 59780, Korea \\ ${ }^{2}$ Dept. of Aqualige Science, Chonnam National University, Yeosu 59626, Korea
}

\begin{abstract}
We determined the morphologic characteristics (body weight and degree of abdomen inflation) of the red spotted grouper, Epinephelus akaara, mother fish producing healthy eggs. Experimental fish were chosen from fish reared in a sea cage. The fish were divided into four size groups by body weight: 400 600, 600 800, 800 1,000, and 1,000 1,200 g and four stages ( $\mathrm{I} \sim \mathrm{IV}$ ) of the degree of abdomen inflation. After hormone treatment, we observed the amount of ovulation-induced eggs, and rates of buoyancy, fertilization, embryonic survival, and hatching. As a result, mother fish with a body weight of $600 \mathrm{~g}$ or more spawned, and the fertilization rate, embryonic survival rate, and hatching rate were high in the 800 1,000 $\mathrm{g}$ range, thus showing effective ovulation induction. As a result of dividing the degree of abdomen inflation based on the anal fin of the mother fish into I-IV stages and determining hormone treatment time, the GSI was $0.9 \pm 0.2 \%$ at stage I, $2.3 \pm 0.2 \%$ at stage II, $5.6 \pm 0.2 \%$ at stage III, and $7.9 \pm 0.9 \%$ at stage IV. The flotation rate and hatching rate were highest at stage III, and the fertilization rate and embryonic survival rate were highest at stage IV. Therefore, in terms of egg quality, the amount of eggs collected per mother fish, maturation, and histology were different depending on the degree of abdomen inflation. At stage III, where the abdomen inflation degree of the mother fish was based on the basal part of the dorsal fin relative to the height of the anal fin was 1 , the egg quality was highest.
\end{abstract}

Key words : Red spotted grouper, Epinephelus akaara, Egg quality, Gonadosomatic Index (GSI), Ovulation induction, Hormone (LHRHa)

\section{INTRODUCTION}

Fish in the Serranidae family have a market value of more than 3 trillion won worldwide and are consumed at high prices in regions of China. In addition, they are mainly cultured in Asia (Kohno et al., 1993; Harikrishnan et al., 2012). Among them, the red spotted grouper, Epinephelus akaara, is distributed in China, Taiwan, southeast Asia, and the southern and central regions of Japan, much of which is where sub-tropical and tropical rocks and coral reefs are located. In Korea, they inhabit Jeju Island in the south and are in Sori-do and Yokji-do in the north, as well as in some southern coastal areas, especially the Geomundo shore region, which is the center of distribution (Kohno et al., 1993; Harikrishnan et al., 2012). Studies on red spotted grouper have investigated spawning habits, the early life cycle (Ukawa \& Higuchi, 1966), gonad development (Hwang et al., 1988), and sperm cryopreservation (Qiutao et al., 2011). In Korea, there have been many studies on red spotted grouper: hepatocyte nuclear changes in fish

Manuscript received October 25, 2018, Received in revised form November 10, 2018, Accepted December 2, 2018

${ }^{\dagger}$ Corresponding Author : Chang Gi Hong, South Sea Fisheries Research Institute, National Institute of Fisheries Science, Yeosu 59780, Korea. Tel: +8261-690-8976, Fax : +82-61-685-9073, E-mail: ckhong@korea.kr

This is an Open Access article distributed under the terms of the Creative Commons Attribution Non-Commercial License (http:// creative-commons.org/licenses/by-nc/3.0) which permits unrestricted non-commercial use, distribution, and reproduction in any medium, provided the original work is properly cited. 
larvae (Lee et al., 1998), growth hormone expression (Kang et al., 2003), maturation and sexual reversal (Lee et al., 1998), live food (Lee \& Hur, 1997), egg quality changes (Lee et al., 1997), egg and fish larvae development (Park et al., 2016), and hybrid embryo hatching (Noh et al., 2015). Despite these various studies, there have been few studies on seed production, including technology for securing high-quality embryos and early live foods of the red spotted grouper, which are required in the fishery industry.

One of the most important factors in fishery production is fish seeds with which to secure large amounts of embryos at the same time. However, similar to most of the Serranidae family, red spotted groupers are hermaphroditic fish that undergo protogynous dichogamy and sexual reversal into males when they reach approximately $30 \mathrm{~cm}$ in total length. Therefore, because the frequency of mature males among red spotted grouper caught in nature is very low, obtaining males for securing the necessary sperm for the production of artificial seeds has been recognized as an important issue in seedling production. Thus, the importance of effective management of spawning broodstock has been highlighted. In addition, species-specific reproductive and ecological characteristics make it difficult to control the breeding environment for natural spawning (Toledo et al., 1993; Okumura et al., 2002). In general, embryos of fish, including those in the Serranidae family, are difficult to naturally spawn and rather are produced through hormone treatment (Chen, 1990; Tucker et al., 1994). For this reason, most of the Serranidae family fish embryos are produced through natural spawning induced by hormone treatment after identifying the size of oocytes through cannulation. The embryos are also produced through egg collection by pressing the abdomen of the fish. In Korea, the mother fish are managed in cage cultures or indoor tank cultures for mass production of red spotted grouper seeds, and the mother fish are screened during the spawning season, and embryos are produced by pressing the abdomen after hormone treatment. However, mass production of embryos in the industry requires a great deal of time and labor to identify the maturity of each egg by cannulation. When cannulation is repeatedly performed to determine the maturity of the eggs, the egg quality may be lowered because of the stress on the mother (Cho et al., 2016). In addition, the standard for identifying the maturation period visually without cannulation is unclear. Thus, hormones may be given too early, or the correct hormone treatment time may pass. Therefore, there is a problem in the production of high-quality embryos in large quantities.

Therefore, this study was conducted to establish the hormone treatment time and screening criteria for target mother fish for seed production based on the external form of a red spotted grouper mother candidate group. This study also aimed to provide a framework for stable production of high-quality embryos by easily applying these criteria in mass seed production in the industry. The degree of abdomen inflation of the mother fish based on the anal fin was classified, gonadosomatic index (GSI) was determined, and ovaries and eggs were observed according to the degree of abdomen inflation (Miura et al., 2014). Fertilization rate, floatation rate, embryonic survival rate, and hatching rate based on the degree of abdomen inflation were examined, the possibility of screening mothers based on external forms was confirmed, and the quality of eggs was compared.

\section{MATERIALS AND METHODS}

\section{Experimental fish}

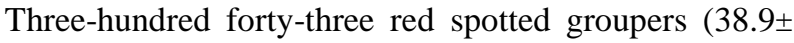
$4.1 \mathrm{~cm}$ in total length, $885.3 \pm 143.5 \mathrm{~g}$ in weight) were caught in along the Geomun-do shore region in Yeosu, Jeollanam-do in June 2013 and cultured in a cage $(5 \times 5 \times 5$ $\mathrm{m})$. In June 2014, mature mother fish were selected and treated with hormones according to the degree of abdomen inflation based on weight and the anal fin of the mother fish (Fig. 1). 


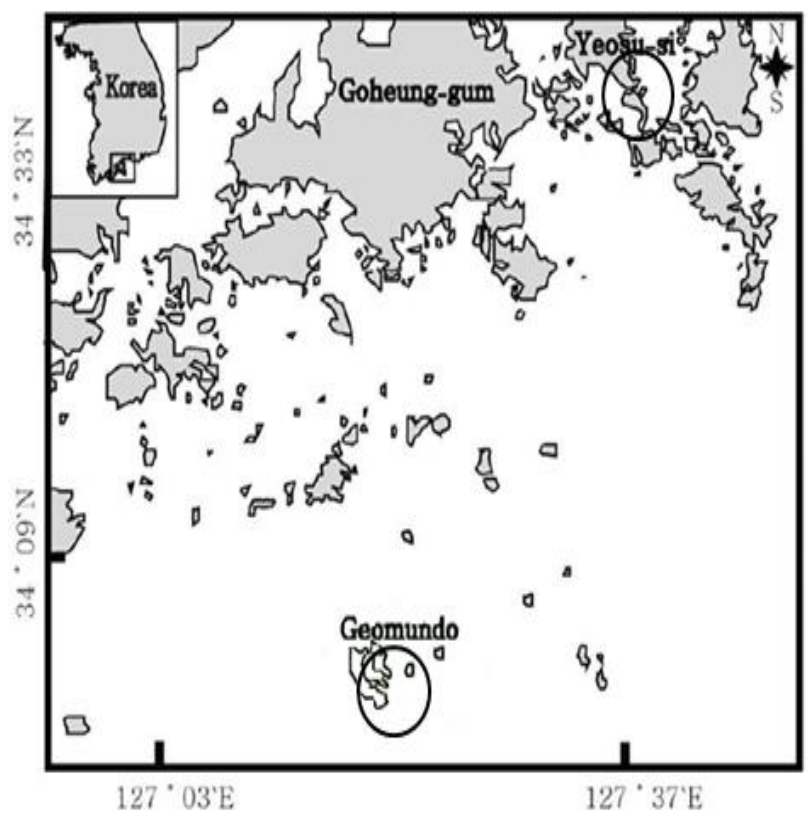

Fig. 1. Map showing the study stations in the Geomundo and Yeosu.

\section{Hormone treatment and artificial fertilization}

LHRHa (des-Gly ${ }^{10}$, D-Ala ${ }^{6}$; Sigma Co. LLC., USA) was used as a hormone for egg maturation and induction of ovulation. It was injected into the lower back muscle at the first spinous ray at a concentration of $100 \mu \mathrm{g} / \mathrm{kg}$ (Liao \& Leano, 2008). The fish were separated into a small cage $(2 \times 2 \times 2 \mathrm{~m})$ for each experimental group.

Forty-eight hours after hormone injection, the abdomen of the test fish was pressured to examine ovulation and the amount of eggs collected per mother fish. Ten collected embryos were observed under a stereoscopic microscope (Olympus CX41, Japan) to measure egg diameter and oil globule diameter. The eggs and semen were artificially fertilized using the dry method, and the fertilization rate and floatation rate were examined. The embryonic survival rate until hatching and hatching rate 12 hours after hatching were determined.

\section{Method}

To determine the minimum body weight required for egg maturation and ovulation induction, 40 female fish (32.5 \pm 1.7 to $39.9 \pm 2.0 \mathrm{~cm}$ in total length, $550.7 \pm 65.5$ to $1,110.0 \pm 65.8 \mathrm{~g}$ in body weight) were divided into four weight groups (400-600, 600-800, 800-1,000, and 1,000$1,200 \mathrm{~g})$. Estimated age was 5-6 (400-600 g), 6-7 (600-800 g), 7-8 (800-1,000 g) and over $8(1,000-1,200 \mathrm{~g})$ years old oocytes (Lee \& Lee, 1996). Then, 10 fish were selected from each group and treated with the hormone. Next, the frequency of spawning, amount of eggs collected per mother fish, fertilization rate, floatation rate, embryonic survival rate, and hatching rate were examined following spawning after hormone treatment (Table 1).

To establish the criteria for screening mother fish and hormone treatment time based on external forms, $60 \mathrm{ma}-$ ture females $(32.6 \pm 4.0$ to $37.7 \pm 2.7 \mathrm{~cm}$ in total length, $9.3 \pm 0.8$ to $14.2 \pm 1.1 \mathrm{~cm}$ in body length, $561.4 \pm 5.4$ to $972.2 \pm 3.8 \mathrm{~g}$ in body weight) were classified by the degree of abdomen inflation into I-IV stages based on the anal fin (Fig. 2, Table 2). Ten mother fish were selected for each stage according to the criteria and treated with the hormone. The amount of eggs collected per mother fish, fertilization rate, floatation rate, embryonic survival rate, and hatching rate were investigated according to stage. Five mother fish were dissected to measure gonad weight and calculate GSI.

Table 1. The results of measurement of brood fishes for range of weight

\begin{tabular}{ccccc}
\hline Variables & $400-600$ & $600-800$ & $800-1,000$ & $1,000-1,200$ \\
\hline TL $(\mathrm{cm})$ & $32.5 \pm 1.7$ & $35.6 \pm 1.5$ & $37.6 \pm 1.7$ & $39.9 \pm 2.0$ \\
BW $(\mathrm{kg})$ & $550.7 \pm 65.5$ & $722.1 \pm 57.0$ & $905.1 \pm 46.7$ & $1,110.0 \pm 65.8$ \\
\hline
\end{tabular}

TL, total length; BW, body weight. 

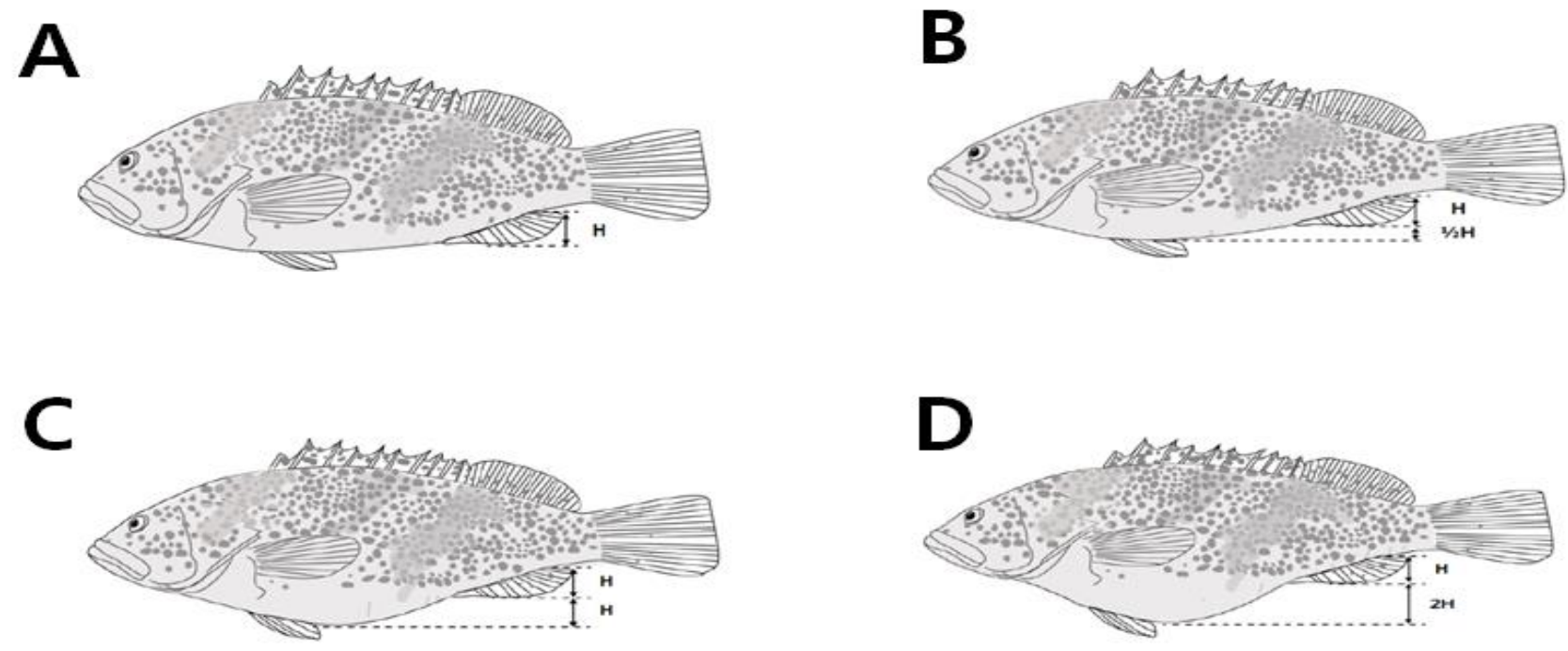

Fig. 2. The diagram of each stage following abdomen inflation degree. A, stage I ; B, stage II; C, stage III; D, stage IV. Stage was distinguished based on the anal fin. Stage I, parallel to the bottom of anal fin and abdomen; Stage II, height of the anal fin was twice height of the abdomen inflation; Stage III, height of the anal fin and abdomen inflation were the same; Stage IV, height of the abdomen inflation was twice height of the anal fin.

The GSI was calculated using the following equation:

Gonadosomatic (GSI, \%)=

100×ovary weight (wet weight, g)

Body weight (wet weight, g)

Table 2. Measurement of divided $E$. akaara depand on abdomen inflation degree

\begin{tabular}{ccccc}
\hline \hline Varia- & \multicolumn{4}{c}{ Stage } \\
\cline { 2 - 5 } bles & $\mathrm{I}$ & $\Pi$ & $\mathrm{II}$ & $\mathrm{IV}$ \\
\hline TL (cm) & $32.6 \pm 4.0$ & $33.5 \pm 4.9$ & $36.9 \pm 3.7$ & $37.7 \pm 2.7$ \\
BD (cm) & $9.3 \pm 0.8$ & $10.4 \pm 0.8$ & $12.5 \pm 1.1$ & $14.2 \pm 1.1$ \\
BW (kg) & $561.4 \pm 5.4$ & $753.4 \pm 2.7$ & $912.5 \pm 2.5$ & $972.2 \pm 3.8$ \\
\hline
\end{tabular}

Each value represents mean $\pm \mathrm{SD}$ ( $\mathrm{n}=10$ for each stage). TL, total length; BD, body depth; BW, body weight. Stage I, parallel to the bottom of anal fin and abdomen; Stage $I$, height of the anal fin was twice height of the abdomen inflation; Stage III, height of the anal fin and abdomen inflation were the same; Stage $\mathrm{IV}$, height of the abdomen inflation was twice height of the anal fin.

\section{Histological observation}

To histologically observe gonadal development at each stage, ovaries fixed in $10 \%$ neutral formalin were re-fixed with Bouin's solution. The fixed tissues were prepared into blocks by the paraffin embedding method. Then, the samples were serially sectioned into $4 \mu \mathrm{m}$ sections by the paraffin sectioning method. Next, the samples were counterstained with Mayer's hematoxylin-eosin (H-E) and observed under an optical microscope (Olympus, CX31) equipped with an image measurement system (FOCUS technology, 2005).

\section{RESULTS}

\section{Frequency of spawning and induction of ovula-} tion by body weight

As a result of examining the ovulation induction effect on the mother candidate group managed in the cages according to body weight, all of the mother fish with a body weight of $600 \mathrm{~g}$ or more artificially spawned eggs, whereas only $70 \%$ of the mother fish with a body weight of 400 


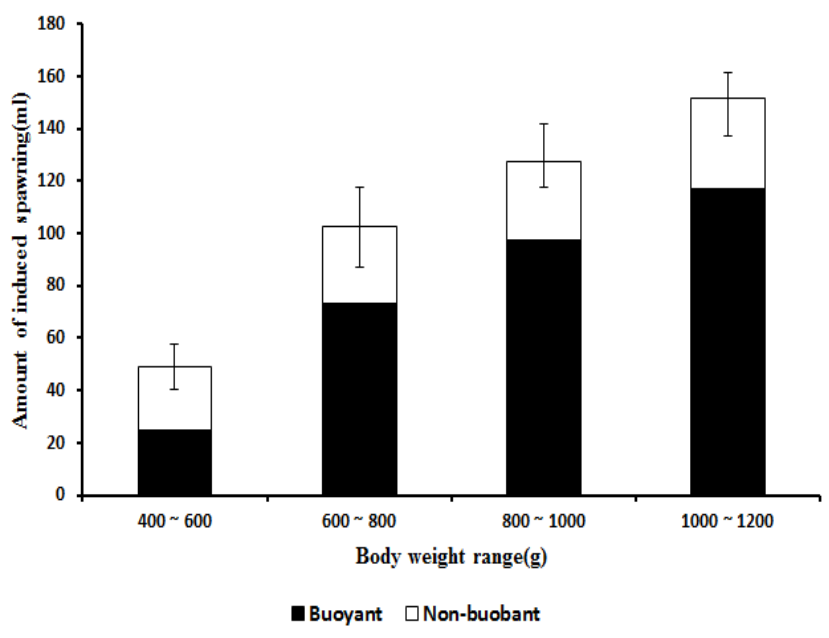

Fig. 3. Amount of induced spawning of E. akaara on body weight range. The bar is indicated a standard deviation ( $\mathrm{n}=10$ of each range).

$600 \mathrm{~g}$ spawned eggs. In the range of $400-600 \mathrm{~g}$, seven mother fish spawned, and the amount of eggs collected per mother was $48.8 \pm 9.9 \mathrm{~mL}$ of which $24.6 \pm 3.5 \mathrm{~mL}$ were floating eggs. In the range of 600-800 g, all 10 mother fish spawned, and the amount of eggs collected per mother was $102.4 \pm 10.4 \mathrm{~mL}$, of which $73.0 \pm 18.2 \mathrm{~mL}$ were floating eggs. In the range of $800-1,000 \mathrm{~g}$, all 10 mother fish spawned, and the amount of eggs collected per mother was $127.4 \pm$ $16.5 \mathrm{~mL}$, of which $97.2 \pm 14.6 \mathrm{~mL}$ were floating eggs. In the range of 1,000-1,200 g, all 10 mother fish spawned, and the amount of eggs collected per mother was $151.8 \pm$ $12.9 \mathrm{~mL}$, of which $117.0 \pm 14.5 \mathrm{~mL}$ were floating eggs (Fig. $3)$. The flotation rate was highest $(85.5 \pm 8.2 \%)$ in the $1,000-1,200 \mathrm{~g}$ range, and it was $76.6 \pm 5.3 \%$ in the 8,00 $1,000 \mathrm{~g}$ range. It was $71.0 \pm 3.2 \%$ in the $600-800 \mathrm{~g}$ range, and it was lowest $(51.2 \pm 7.8 \%)$ in the $400-600 \mathrm{~g}$ range. The highest fertilization rate was $89.8 \pm 9.2 \%$ in the $800-1,000 \mathrm{~g}$ range, and the fertilization rate was $87.8 \pm 18.6 \%$ in the $600-800 \mathrm{~g}$ range. The fertilization rate was $85.4 \pm 2.16 \%$ in the $1,000-1,200 \mathrm{~g}$ range, and it was lowest $(50.2 \pm 22.8 \%)$ in the 400-600 $\mathrm{g}$ range. The embryonic survival rate was highest at $91.8 \pm 25.3 \%$ in the $800-1,000 \mathrm{~g}$ range, and it was $87.5 \pm 38.6 \%$ in the $600-800 \mathrm{~g}$ range. It was $85.6 \pm$ $17.5 \%$ in the $1,000-1,200 \mathrm{~g}$ range and $80.4 \pm 24.5 \%$ (low- est) in the $400-600 \mathrm{~g}$ range. The hatching rate was the highest $(87.8 \pm 4.9 \%)$ in the $800-1,000 \mathrm{~g}$ range. It was $83.5 \pm 18.2 \%$ in the $1,000-1,200 \mathrm{~g}$ range, $79.5 \pm 18.4 \%$ in the $600-800 \mathrm{~g}$ range, and $78.5 \pm 20.5 \%$ (lowest) in the $400-600$ g range (Fig. 4).

\section{Gonadal development and ovulation induction} effects according to the degree of abdomen inflation stage

To establish the criteria for determining the hormone treatment time by the naked eye, the degree of abdomen inflation was divided into I-IV stages based on the anal fin. As a result, at stage I, all mother fish showed normal spawning, but a small number of eggs appeared, and many of them were immature. The average amount of collected eggs per mother fish was small with a value of $9.0 \pm 2.0$ $\mathrm{mL}$, of which $3.8 \pm 2.1 \mathrm{~mL}$ was of floating eggs. At stage II, most of the eggs were mature, and the amount of eggs collected per mother fish was $20.4 \pm 8.3 \mathrm{~mL}$, of which $9.6 \pm 4.3$ $\mathrm{mL}$ was of floating eggs. At stage III, most of eggs were mature, and the amount of eggs collected per mother fish was $137.4 \pm 18.1 \mathrm{~mL}$, of which $112.6 \pm 8.4 \mathrm{~mL}$ was of floating eggs. At stage IV, most eggs were over-mature, and the amount of eggs collected per mother fish was $150.2 \pm 16.2$ $\mathrm{mL}$, of which $93.6 \pm 26.4 \mathrm{~mL}$ was of floating eggs (Fig. 5).

The flotation rate was highest $(82.6 \pm 8.6 \%)$ at stage III, followed by $61.6 \pm 12.4 \%$ at stage IV, $47.7 \pm 19.0 \%$ at stage II, and $44.7 \pm 29.1 \%$ at stage I. The fertilization rate was highest $(85.5 \pm 2.16 \%)$ at stage IV, followed by $82.4 \pm 9.2 \%$ at stage III, $42.5 \pm 18.6 \%$ at stage II, and $5.8 \pm 8.1 \%$ at stage I. The embryonic survival rate was highest $(94.5 \pm 17.5 \%)$ at stage IV, followed by $85.4 \pm 25.3 \%$ at stage III, $50.8 \pm$ $24.5 \%$ at stage I, and $45.5 \pm 38.6 \%$ at stage II. The hatching rate was highest $(88.8 \pm 4.9 \%)$ at stage III, followed by $85.5 \pm 18.2 \%$ at stage IV, $61.5 \pm 20.5 \%$ at stage I, and $59.5 \pm 44.4 \%$ at stage II (Fig. 6).

The egg characteristics (egg diameter and oil globule diameter) and GSI were measured to investigate the sexual 

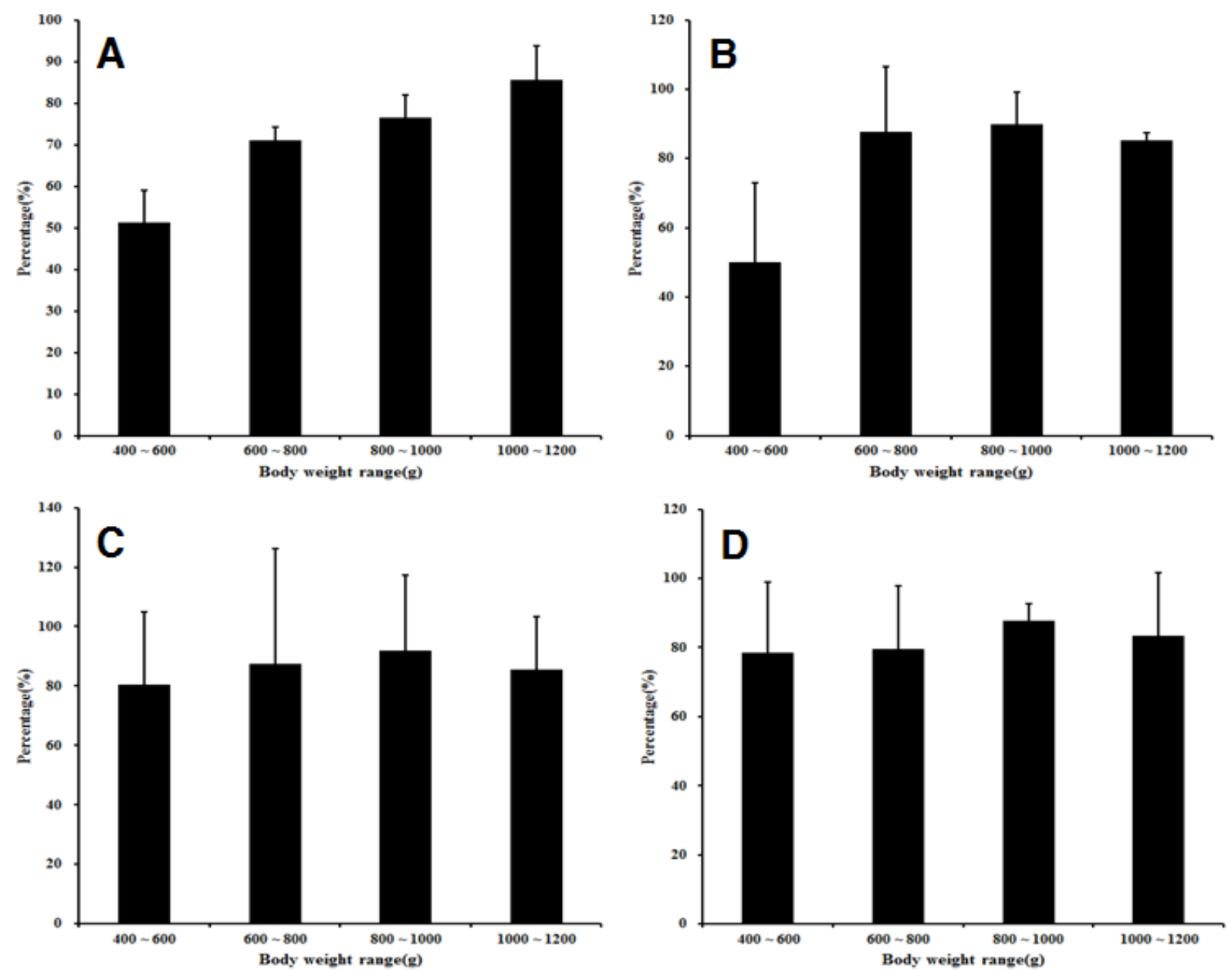

Fig. 4. Rate of buoyant, fertilization, embryonic survival, and hatching of $E$. akaara versus body weight range. A, buoyant rate; $\mathrm{B}$, fertilization rate; $\mathrm{C}$, embryonic survival; $\mathrm{D}$, hatching rate. The bar is indicated a standard deviation.

maturity stage according to the degree of abdomen inflation. As a result, at stage I, the egg diameter was $0.76 \pm 0.01$ $\mathrm{mm}(0.74-0.77 \mathrm{~mm})$, and oil globule diameter was $0.17 \pm$ $0.01 \mathrm{~mm}(0.16-0.19 \mathrm{~mm})$. At stage II, the egg diameter was $0.75 \pm 0.02 \mathrm{~mm}(0.74-0.80 \mathrm{~mm})$, and oil globule diameter was $0.16 \pm 0.01 \mathrm{~mm}(0.15-0.17 \mathrm{~mm})$. At stage III, the egg diameter was $0.75 \pm 0.01 \mathrm{~mm}(0.73-0.78 \mathrm{~mm})$, and the oil globule diameter was $0.17 \pm 0.01 \mathrm{~mm}(0.16-0.17 \mathrm{~mm})$. At stage IV, the egg diameter was $0.73 \pm 0.02 \mathrm{~mm}(0.72$ $0.75 \mathrm{~mm}$ ), and the oil globule diameter was $0.16 \pm 0.01 \mathrm{~mm}$ $(0.16-0.17 \mathrm{~mm})$. Thus, the egg diameter was highest at stage I and lowest at stage IV. There was no significant difference in oil globule diameter based to stage (Table 3 ).

The GSI value was $0.9 \pm 0.2 \%$ at stage $I$ and $2.3 \pm 0.2 \%$ at stage II. The GSI value at stage III was $5.6 \pm 0.2 \%$. Lastly, stage IV showed a GSI value of $7.9 \pm 0.9 \%$ (Fig. 7).

Histological examination of the gonads revealed that stage I and stage II consisted mostly of early oocytes and nuclei occupied a high proportion of the cytoplasm (Fig. 8A and B). At stage III, most eggs were mature eggs with accumulated yolk, and at stage IV, almost all eggs were mature (Fig. 8C and D).

\section{DISCUSSION}

In general, fish become mature and spawn at a specific season, exhibiting a reproductive cycle around the spawning season. Water temperature and photoperiod have been 


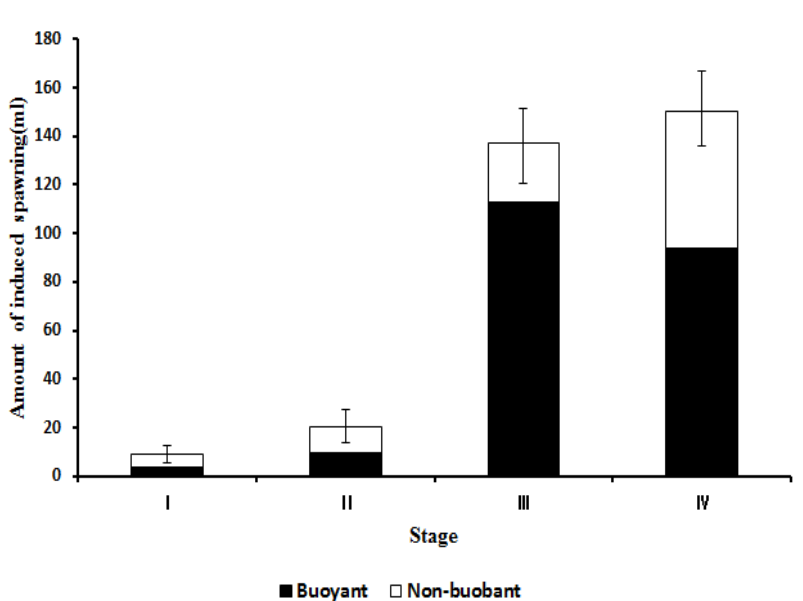

Fig. 5. Amount of induced spawning of each stage following abdomen inflation degree $(n=10$ of each stage). Stage I, parallel to the bottom of anal fin and abdomen; Stage $\amalg$, height of the anal fin was twice height of the abdomen inflation; Stage III, height of the anal fin and abdomen inflation were the same; Stage IV, height of the abdomen inflation was twice height of the anal fin.

reported to be environmental factors controlling the reproductive cycle (De Vlaming, 1972, De Vlaming, 1975; Lee

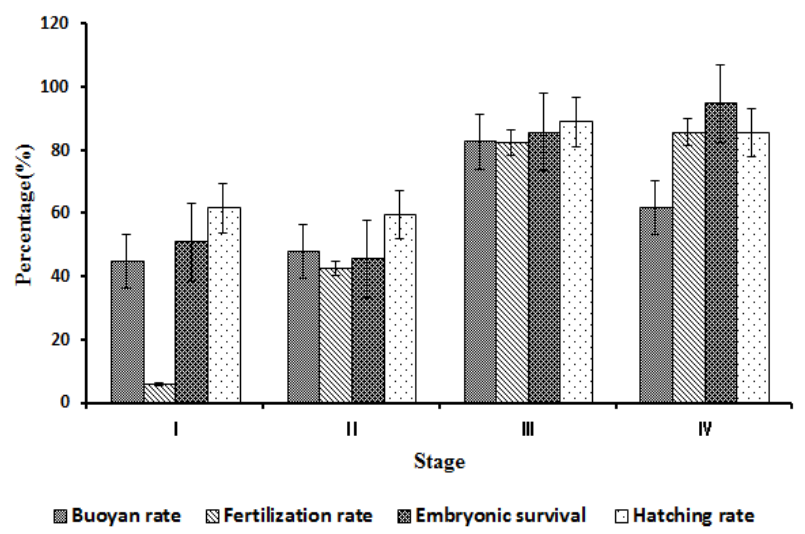

Fig. 6. Percentage of buoyant, fertilization, embryonic survival, and hatching rate of each stage following abdomen inflation degree. Stage I, parallel to the bottom of anal fin and abdomen; Stage II, height of the anal fin was twice height of the abdomen inflation; Stage III, height of the anal fin and abdomen inflation were the same; Stage $\mathrm{IV}$, height of the abdomen inflation was twice height of the anal fin.
Table 3. The results of measurement and statistical analysis of egg and oil globule on concentration of hormone

\begin{tabular}{ccc}
\hline \hline Variables & Eggs $(\mathrm{mm})$ & Oil globules $(\mathrm{mm})$ \\
\hline Stage I & $0.76 \pm 0.01$ & $0.17 \pm 0.01$ \\
Stage II & $0.75 \pm 0.02$ & $0.16 \pm 0.01$ \\
Stage III & $0.75 \pm 0.01$ & $0.17 \pm 0.01$ \\
Stage IV & $0.73 \pm 0.02$ & $0.16 \pm 0.01$
\end{tabular}

Each value represents mean \pm S.D. ( $n=10$ for each female). Stage I, parallel to the bottom of anal fin and abdomen; Stage $I$, height of the anal fin was twice height of the abdomen inflation; Stage III, height of the anal fin and abdomen inflation were the same; Stage IV, height of the abdomen inflation was twice height of the anal fin.

et al., 1984). According to the spawning time, fish were classified into six types: spring, spring-summer, springfall, summer, fall, and winter (Aida, 1991). It was considered that gonad maturation of red spotted groupers, which belong to the summer spawning type, was influenced by the increase in temperature and long photoperiod. In addition, when the oocytes of the fish were classified into synchronous, group-synchronous, and asynchronous based to the development of oocytes (Wallace \& Selman, 1981; De Vlaming, 1983), each mother fish spawned normal eggs, immature eggs, or over-mature eggs simultaneously. Red spotted groupers, which have oocytes during the yolk vesicle and yolk globule stages in the mature ovary simultaneously belong to the asynchronous type, which spawns at multiple times.

At weight range 400-600 g group, collected eggs was the least and most of the eggs were immature. It is supposed to be more than $600 \mathrm{~g}$ in order to produce mature eggs stably. It is considered that size of the mother fish affects the maturation of eggs.

The size of oocytes was measured through cannulation during the spawning season for seed production to deter- 


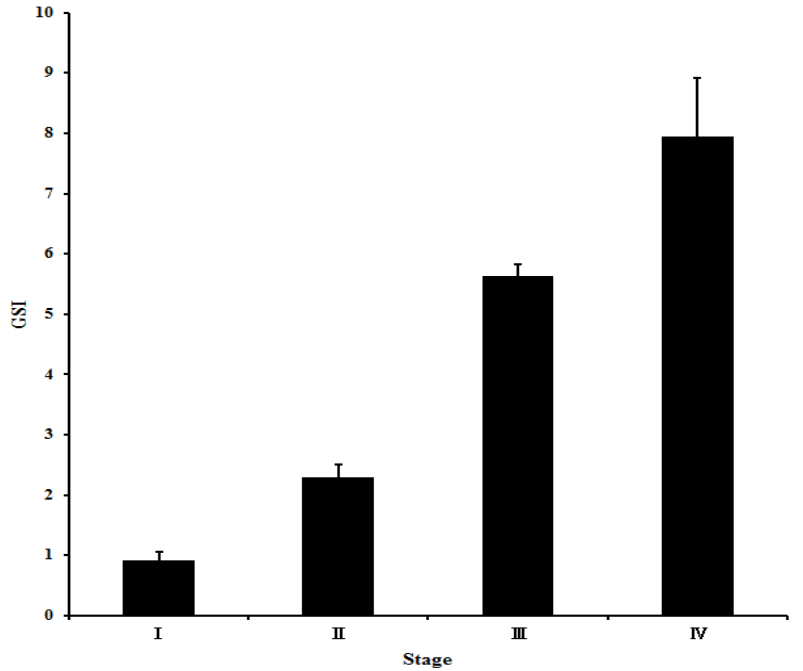

Fig. 7. GSI of each stage following abdomen inflation degree. GSI, Gonadosomatic index. Stage I, parallel to the bottom of anal fin and abdomen; Stage $I$, height of the anal fin was twice height of the abdomen inflation; Stage III, height of the anal fin and abdomen inflation were the same; Stage IV, height of the abdomen inflation was twice height of the anal fin.

mine hormone treatment time. In this study, we aimed to verify the applicability of determining hormone treatment time through the degree of abdomen inflation measured by the naked eye instead of determining hormone treatment time by measuring the size of oocytes through existing cannulation for seed production of E. septemfasciatus. As a result, the quality of eggs differed according to the degree of abdomen inflation of the mother fish in terms of the amount of eggs collected per mother fish, maturation degree, and histology. At stage III, where the abdomen inflation degree of the mother fish was 1 based on the basal part of the dorsal fin relative to the height of the anal fin, the egg quality was the highest. At stage I with the degree of abdomen inflation of 0 , the amount of eggs collected per mother fish was the least and most of the eggs were immature. At stage II where the degree of abdomen inflation was $1 / 2$, most of eggs were mature, but the amount of eggs per mother fish was small. At stage III, eggs were
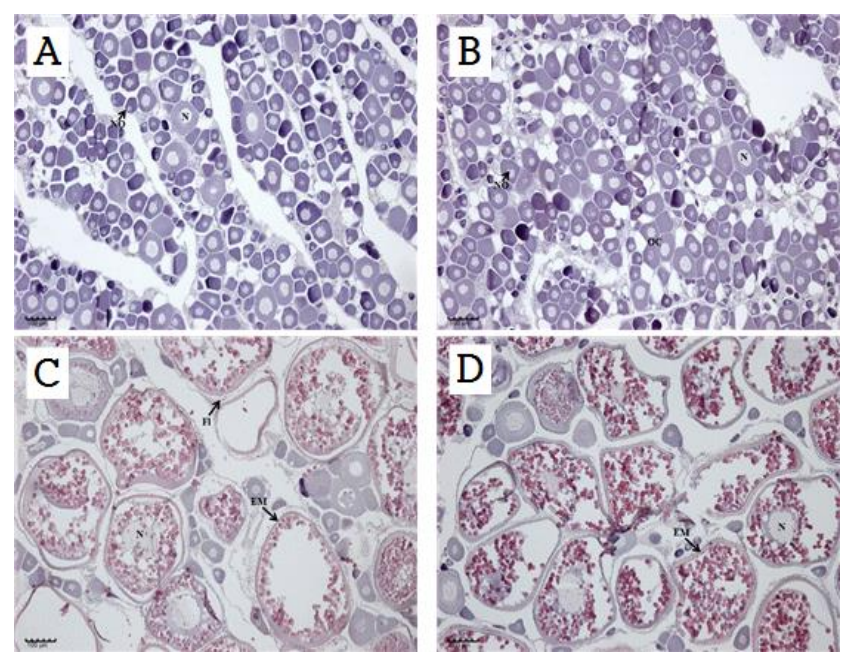

Fig. 8. Histological observation of ovary on each stage.

A, stage I ; B, stage II; C, stage III; D, stage IV Stage I, parallel to the bottom of anal fin and abdomen; Stage II, height of the anal fin was twice height of the abdomen inflation; Stage III, height of the anal fin and abdomen inflation were the same Stage IV, height of the abdomen inflation was twice height of the anal fin. Em, egg membrane; Fl, follicle layer; N, nucleus; $\mathrm{NO}$, nucleolus; OC, ovarian; Og, oogonium.

mature with accumulated yolk, the flotation rate was highest with a value of $82.6 \pm 8.6 \%$, and the hatching rate was highest with a value of $88.8 \pm 4.9 \%$. At stage IV, the amount of eggs collected per mother fish was greatest; however, most of the eggs were mature histologically, and overmature eggs were observed. It was necessary to study the specific time so that ovulation induction is more stable by subdividing maturity stages III and IV.

Temperate bony fish that spawn in a certain season undergo body changes according to gonad development during the spawning season. The GSI has been most widely used to identify the spawning season. The GIS at stage III, which showed the highest egg quality of red spotted grouper, was $5.6 \pm 0.2 \%$, which was significantly different from the highest value (2.42\%) of Hwang et al. (1998). The highest value of $7.69 \%$ in Lee et al. (1998) was similar to the GSI at stave IV in this study. In addition, the GSI 
was higher than $4.68 \%$ of the Serranidae family E. septemfasciatus (Cho et al., 2016). Compared with other Perciformes fish, the results of our study were higher than the $4.47 \%$ in Micale et al. (1996) for Diplodus puntazzo, 0.06\%$1.86 \%$ in Papadaki et al. (2008), and $1.14 \%$ in Hernandez et al. (2003). However, the results in this study were lower than the $8.21 \%$ of Perca fluviatilis (Abdulfatah et al., 2013), $10.8 \%$ of mandarin fish (Lee et al., 2012), $12.85 \%$ of dragonet (Baeck \& Huh, 2004), and 7.50\% of spotted sea bass (Kim et al., 2001). These differences may have resulted from the GSI being affected by differences in the age and size of mother fish caught in nature.

In conclusion, the results of this study suggest that hormone treatment time and mother screening criteria can be determined by visual methods, such as the degree of abdomen inflation, for seed production of red spotted grouper. If visual indicators that can be used as criteria for determining hormone treatment time and screening of mother fish are identified in addition to the degree of abdomen inflation, it would be possible to easily determine hormone treatment time and screen mother fish without causing stress to the mother fish, as it would not require cannulation. Thus, such criteria could be applied in the industry.

\section{ACKNOWLEDGMENTS}

This work was supported by a grant from the National Institute of Fisheries Science (R2018018).

\section{REFERENCES}

Abdulfatah A, Fontaine P, Kestemont P, Milla S, Marie M (2013) Effects of the thermal threshold and the timing of temperature reduction on the initiation and course of oocyte development in cultured female of Eurasian perch Percafluvi atilis. Aquaculture 376-379:90-96.

Aida K (1991) Environmental regulation of reproductive rhythms in teleosts. Bull Inst Zool Acad Sin Monogr
16:173-187.

Baeck GW, Huh SH (2004) Maturation and spawning of Repomucenus valenciennei collected in Gwangyang Bay, Korea. Korean J Ichthyol 16:89-93.

Chen LC (1990) Grouper culture. In: Aquaculture in Taiwan. Fishing News Books, Oxford, pp 103-107.

Cho JK, Hong CG, Park JY, Son MY, Park JM, Han KH, Kim KM. 2016. Ovulation induction effect of Sevenband Grouper, Epinephelus septemfasciatus in size and abdomen inflation degree of mother fish. Korean J Ichthyol 28:260-266.

De Vlaming VL (1972) The effects of temperature and photoperiod on reproductive cycling in the estuarine gobiid fish, Gillichthys mirabilis. Fish Bull 70:11371152.

De Vlaming VL (1975) Effects of photoperiod and temperature on gonadal activity in the cyprinid teleost, Notemigonus crysoleucas. Biol Bull 148:402-415.

De Vlaming VL (1983) Oocyte development patterns and hormonal involvement among teleosts. In: Rankin JC, Pitcher TJ, Duggan R (ed), Control Processes in Fish Physiology. Croom Helm, London, pp 176-199.

Harikrishnan R, Kim JS, Balasundaram C, Heo MS (2012) Immunomodulatory effects of chitin and chitosan enriched diets in Epinephelus bruneus against Vibrio alginolyticus infection. Aquaculture 326-329:46-52.

Hwang SI, Lee YD, Song CB, Rho S (1998) Gonadal development and the effects of $17 \alpha$-methyltestosterone on sex inversion of the red spotted grouper, Epinephelus akaara. J Aquac 11:173-182.

Hernandez MD, Egea MA, Rueda FM, Martinez FJ, Garcia B (2003) Seasonal condition and body composition changes in sharpsnout seabream (Diplodus puntazzo) raised in captivity. Aquaculture 220:569-580.

Kang GY, Song CB, Lee JH (2003) Cloning of growth hormone complementary DNA from red spotted grouper (Epinephelus akaara) and its expression in E. coli. $\mathrm{J}$ Aquac 16:110-117. 
Kim IS, Choi Y, Kim BJ (2001). Percoidei fishes of Korea. Korea Research Institute of Bioscience and Biotechnology, Daejeon, Korea, p 279.

Kohno H, Diani S, Supriatna A (1993) Morphological development of larval and juvenile grouper, Epinephelus fuscoguttatus. Jpn J Ichthyol 40:307-316.

Lee TW, Lee CK (1996) Age and growth of Epinephelus akaara in the South Western Sea of Korea. Korean J Ichthyol 8:16-22.

Lee CK, Hur SB (1997) Yolk resorption, onset of feeding and survival potential of larvae of red spotted grouper, Epinephelus akaara. J Aquac 10:473-483.

Lee CK, Hur SB, Park S, Kim BG (1997) Qualities of spawned eggs during the spawning period in red spotted grouper, Epinephelus akaara. J Aquac 10:463-472.

Lee CK, Hur SB, Ko TS, Park S (1998) Maturation, sex ratio and sex-reversal of red spotted grouper, Epinephelus akaara. J Aquac 11:573-580.

Lee TY, Hanyu I, Furukawa K (1984) Effects of photoperiod and temperature on the gonadal activity in small filefish, Rudarius ercodes. Korean J Fish Aquat Soc 17:523-528

Lee WO, Baek JN, Lee JH, Kim KH, Kim CH, Yoon SW (2012). Sexual maturation and feeding habit of Korean mandarin fish, Siniperca scherzeri (Perciformes, Centropomidae) in the Seomjin river and Imjin river, Korea. Kor J Env Eco 26: 57-66.

Liao IC, Leano EM (2008) The Aquaculture of Grouper. Asian Fisheries Society, pp 49-60.

Micale V, Perdichizzi F, Basciano G (1996) Aspects of the reproductive biology of the sharpsnout seabream Diplodus puntazzo (Cetti, 1777). I. Gametogenesis and gonadal cycle in captivity during the third year of life. Aquaculture 140:281-291.

Miura C, Yoshihara Y, Shimizu-Yamaguchi S, Hayashi D, Hamada K, Takeda Y, Miura M, Miura T (2014) Controlled feeding alleviates the reduced growth associated with spawning in farmed yellowtail (Seriola quinqueradiata). Aquaculture 424-425:10-17.

Noh CH, Kim KS, Myoung JG, Cho JK, Yun NJ, Lim HG, Bang IC (2015) The hatchability of fertilized eggs of interspecific hybrid between red spotted grouper (Epinephelus akaara) and brown-marbled grouper (E. fuscoguttatus). Korean J Ichthyol 27:16-20.

Okumura S, Okamoto K, Oonori R, Nakazono A (2002) Spawning behavior and artificial fertilization in captive reared red spotted grouper, Epinephelus akaara. Aquaculture 206:165-173.

Papadaki M, Papadopoulou M, Siggelaki I, Mylonas CC (2008) Egg and sperm production and quality of sharpsnout sea bream (Diplodus puntazzo) in captivity. Aquaculture 276:187-197.

Park JY, Cho JK, Son MH, Kim KM, Han KH, Park JM (2016) Artificial spawning behavior and development of eggs, larvae and juveniles of the red spotted grouper, Epinephelus akaara in Korea. Dev Reprod 20:31-40.

Qiutao H, Gang L, Kai C, Enhui Z, Qiongshan F, Hansheng W, Jing L, Changjiang H, Qiaoxiang D (2011) Sperm cryopreservation of the endangered red spotted grouper, Epinephelus akaara, with a special emphasis on membrane lipids. Aquaculture 318:185-190.

Toledo JD, Nagi A, Javellana D (1993) Successive spawning of grouper, Epinephelus suillus (Valenciennes), in a tank and a floating net cage. Aquaculture 115:361-367.

Tucker Jr. JW, Parsons JE, Ebanks GC, Bush PG (1994) Induced spawning of Nassau grouper Epinephelus striatus. J World Aquac Soc 22:187-191.

Ukawa M, Higuchi M (1966). Spawning habits and early life history of a serranid fish, Epinephelus akaara. Japan J Ichthyol 13:156-161.

Wallace RA, Selman K (1981). Cellular and dynamic aspects of oocyte growth in teleosts. Am Zool 21:325343. 